\title{
Effect of Salting Process on Fish Quality
}

Hafez N.E1, Awad, A.M' Ibrahim S.M², Mohamed H.R ${ }^{2 *}$ and El-Lahamy A.A ${ }^{2}$

${ }^{1}$ Department of Food Science and Technology, El-Fayoum University, Egypt

${ }^{2}$ Fish Processing and Technology Laboratory, National Institute of Oceanography and Fisheries, Egypt

*Corresponding Author: Hassan Rabea Mohamed, Fish Processing and Technology Laboratory, Fisheries Division, National Institute of Oceanography and Fisheries, Egypt, E-mail: hassanaboali66@yahoo.com

Received date: September 03, 2019; Accepted date: September 10, 2019; Published date: September 16, 2019

Citation: Hafez N.E, Awad, A.M, Ibrahim S.M, Mohamed H.R and El-Lahamy A.A. Effect of Salting Process on Fish Quality. Nutrition and Food Processing, 2(1); Doi:10.31579/2637-8876/011

Copyright: (C) 2019 Hassan Rabea Mohamed, This is an open-access article distributed under the terms of the Creative Commons Attribution License, which permits unrestricted use, distribution, and reproduction in any medium, provided the original author and source are credited.

\begin{abstract}
:
Salting is one of the oldest techniques known to man for the preservation and increasing of shelf life of fish, and was in use long before other processes such as smoking, drying, canning, marinating, etc. The present study can be summarized in identifying the changes in chemical composition, physicochemical parameters, microbiological quality and sensory properties associated with fish salting and storage periods.
\end{abstract}

Keywords: salting; chemical composition; sensory properties; microbial quality; quality attributes

\section{Introduction}

Fish when are not consumed fresh; various methods of preservation particularly salting, drying, smoking, frying and freezing are normally used. However, salting followed by drying is very common because it is cheaper, does not need sophisticated equipment and is easily adaptable by local processors. In addition, salted fish products are popular in many countries around the world. Salted fish products have been shown to be safe for millenniums, even in developed countries [1, 2]. Salting techniques are simple and involve salt crystals or brine. There are three types of salting of fish: dry salting, wet salting and a combination of the two methods. Length of salting period as well as salt concentration depends on the expected final product. Salt uptake depends on many factors including the quality and chemical composition of raw material, species, muscle type, fish size, fillet thickness, weight, physiological state, salting method, brine concentration, duration of salting process and fish to salt ratio $[3,4,5,6,7]$. These factors could subsequently affect the quality as well as further processing such as drying and storage. Lowering the water activity of fish can be accomplished by drying, salting or a combination of both. Many traditional drying/curing processes use salt as a Means of lowering water activity. The salt acts to bind water molecules. A Saturated solution of common salt has a water activity of close to 0.75.Thus salting is an effective way of avoiding toxins associated with the growth of bacteria such as Clostridium $s p$ [8] . Sometimes, the flavor of the product could be enhanced in extended shelf life products, depending upon the added ingredients. For example, apart from inhibiting microorganisms, salting enhances flavor and texture of foods.

\section{Effect of salting on chemical composition of fish:}

\section{Moisture content.}

The moisture content decreased from $78.31 \%$ in fresh fish to
$67.15 \%$ after six weeks of brining of Mullet fish meat (Mugil cephalus) [9]. The moisture content were $72-74 \%$ with $16-18 \%$ loss in weight for the light salting, $63.70 \%$ with $20-26 \%$ loss in weight for medium salting and $57.5 \%$ with $30 \%$ loss in weight for heavy salting [10 ]. The moisture content in lightly salted Mullet fish decreased slightly during the first week of salting and reached maximum decline on the third week. While it remained constant at the end of salting process [11]. A progressive loss in moisture content of Mullet accompanied with slight increase in protein and lipid level [12]. The moisture continuously decreased either after brining or cold-smoking processes and storage period for 120 days at $4 \mathrm{c}$ of both common Carp and Herring species [13]. The moisture content of the finished product of salt-cured fish in parallel with the water activity plays an important role in the determination of keeping quality or shelf life of such product in addition to the salt content [14]. After the salting process of anchovy, the moisture content decreased from $75.5 \%$ in fresh fish to $54.16 \%$ in salted fish and the loss in moisture content was accompanied by increase in the salt and ash contents. The decrease in moisture content and increase in the salt and ash of salted anchovy were significant only during the first week of ripening [15]. The changes in moisture contents offresh and brine salted rainbow trout were given moisture in muscle in freshwas $76.59 \%$ and $75.02 \%$ in brine salted $8 \%$ and $75.06 \%$ in brine salted 20 $\%$ and $69.77 \%(\mathrm{w} / \mathrm{w})$ in dry salted fish samples[16].

\section{Protein content.}

The crude protein decreased by $6.7 \%$ (dry wt.) when the Mullet fish brined in $20 \% \mathrm{NaCl}$ for $48 \mathrm{hr}$. at $20^{\circ} \mathrm{C}$ [12]. Also, [15]. Found that the protein content in anchovy muscles decreased markedly after six weeks from $20.44 \%$ to $17.81 \%$. The protein content in brine remained constant after six weeks and then decreased appreciably until the end of the ripening ( 0.94 to $0.56 \%)$. In salted fish, where the salt concentration reaches $20 \%$ [17]. High ionic strength causes contraction of the myofibrils [18]. And dehydration of the proteins in a process known as "salting out" $[19,20]$. Also, the $\mathrm{pH}$ of the medium and the type of salts used for salting can 
influence the degree of protein denaturation [21,22], thus affectingprotein functionality to a greater or lesser degree. During the salting process, the changes in protein structure such as protein denaturation of cod occurred when brine concentration was raised from 20 to $25 \%$ due tothe protein salting-out and the yield got lower than that obtained when using $20 \%$ brine [23]. The salting entails loss of water and uptake of salt.This affects the conformation of the muscle proteins, causing changes in waterholding capacity (WHC) and subsequent protein denaturation [24].Also, found that dry-salting reduced the water-holding capacity(WHC) of the muscle, from $3.32 \mathrm{~g}$ water retained/g protein in unsalted cod to final values ranging from 1.95 to $2.33 \mathrm{~g}$ water retained/g protein in dry salted fillets. The total protein values of fresh, brine salted and dry salted rainbow trout and extracts were given protein in muscles in fresh was $76.53 \%$ and $73.31 \%$ in brine salted $8 \%$ and $72.47 \%$ in brine salted $20 \%$ and $71.29 \%(w / w)(w / w)$ in dry salted rainbow trout. An increase in the protein content in the salting medium was found during wet salted Tilapia production. Also, the protein was solubility to a greater extent when the salting time increased. The increase in the soluble protein content was primarily due to the salting-in effect [16]. The ionic strength of $\mathrm{NaCl}$ solution used as a brining medium was approximate 4.27. This ionic strength resulted in the solubilisation of both sarcoplasmic and myofibrillar proteins especially with increasing salting time. At the ionic strengths $>0.15$, the inter-fibrillar spaces become larger due to electrostatic shielding effect from salt ions binding to charged parts of the filaments $[25,26]$.

\section{Fat content.}

The rancidity of salted fish, which negatively affect the quality of the finished product, was found to increase according to many factors such as: time of salting, fish species, oil content, degree of unsaturation of oil, presence or absence of haematin pigments and presence or absence of sunlight [27]. Fish body oils are very susceptible to oxidation by atmospheric oxygen leading to rancid off flavors. Such undesirable flavors decrease the acceptability of the fish product, there is some degree of rancidity is considered normal [28]. Total lipid content is highly variable in fish ranging from under $0.6 \%$ in cod to a reported $25.5 \%$ in Mackerel. In addition to species variability; lipid content varies with anatomical, sex, season and diet [28, 29]. [30] Found that the decreasing oil yield may be due to enzymatic spoilage of the fish lipids. This spoilage converts triglycerides and phospholipids into free fatty acids and other products such as oil-soluble di- and monoglycerides and water soluble phosphate esters. [31] Found that the lipid content of salted fermented Bouri fish decreased accompanied by an increase in peroxide value and production of free fatty acids. [32] Reported that the total lipids content of fish decreased as a result of salting and curing process. The decrease in lipid contents may be attributed to the hydrolysis of triglycerides and phospholipids, which is catalyzed by lipases and phospholipases and release of free fatty acids that is soluble in water then leaching into the drip [9.33]. The higher loss in lipid content of dried Mullet may be due to more protein denaturation as a result of high content of salt in tissues to an extent that may cause decrease in water holding capacity (WHC) and emulsifying properties of proteins [12]. [15] Observed that the content of anchovy from fat remained constant (3-5) during the ripening process, although slight variability was apparent. The fat content of anchovy was 3.24 in fresh fish and 3.74, 3.45, 4.87, 3.55, 4.22, 4.60, 4.87, 4.70 and $4.79 \%$ after $1,2,3,4,5,6,7,8$ and 9 weeks of salting anchovy, respectively. [16] found that the changes in fat content of fresh and brine salted rainbow trout were given fat in muscle in fresh was $13.75 \%$ and $12.11 \%$ in brine salted $8 \%(\mathrm{w} / \mathrm{w})$ and $12.87 \%$ in brine salted $20 \%(\mathrm{w} / \mathrm{w})$ and $11.46 \%$ in dry salted rainbow trout.

\section{Salt and ash content.}

The higher brine concentration caused dehydration of the fillets, due to the difference in solute concentration between the brine solution and the inherent muscle water; water migrated from fish muscle to the high brine solution [4]. The increase in salt content in the muscle resulted in a decrease in the Aw of muscle. Increased water phase salt content corresponded with decreased Aw and increased product ash content. Increased salt content promoted protein-protein interactions and decreased protein-water interactions. Salt preserves the fish by dehydrating tissue, increasing water phase salt, and decreasing Aw. The final salt concentration in the different dry salted samples, expressed chiefly as $\%$ ash, did not generally correlate with the concentration in the corresponding brined samples [24].The yield or the weight gain of salted products depends not only on the brine concentration, but also on the brining time and temperature. The weight gain of salted Herring at low brining temperature was higher than that at high brining temperature and increased weight gain seemed possible by further extension of the brining time [34]. [35] Reported that $\mathrm{NaCl}$ present in the product would be located in the liquid phase at a saturation concentration. Since the saturated brine concentration is around $25 \%(\mathrm{w} / \mathrm{w})$, the evaporation of three units of water implies the formation of one unit of $\mathrm{NaCl}$ crystals. Salting involves salt intake with a saturation of the liquid phase. During the drying process, the saturation of the cod liquid phase would be maintained by the precipitation of the $\mathrm{NaCl}$, thus forming salt crystals, mainly on the cod surface. [6] Found that the rate of salt uptake was different whether Sardine fish salting was made by brining or by dry salting. Thus, during the first four salting hours, and for both salting methods, the rate of salt diffusion in the fish flesh were high, although much higher in the dry salting case. After $24 \mathrm{~h}$ salting, salt content increase to a constant of $31 \%(\mathrm{db})$ for brining method, and of $45 \%(\mathrm{db})$ for dry salting. [36] Found a salt content equal to $34 \%$ (db) when salting yellow tail (Trachurus mcullochinichols) in $21 \%$ brine. [6] reported that However, the equilibrium salt uptake was not reached before $50 \mathrm{~h}$. although dry salting gives the most rapid rate of reduction in moisture content and the lowest final moisture content during salting, it also gave a slower rate of reduction of moisture and higher final water content during drying. Hence water content at the end of the drying period is less important for brined fish at $21 \%$. When salt brine or dry salt are used as salting agents, two main simultaneous flows are usually generated; water loss and salt uptake. The salt uptake and water loss depend on the contact area and initial weight [37]. [38] Found that $\mathrm{NaCl}$ content of the salted sea bass fillets increased throughout the salting process, with the highest increase for salt concentration on dry basis, since during the process besides the incorporation of solutes into the muscle, osmotic dehydration occurs. Water from the fish muscle goes out to the salted sea bass fish surface during the salting process, due to the effect of salt as dehydration agent, dissolving the sodium chloride present in the surface. Consequently, brine is formed on the fillet surface. Some of the salt from this brine penetrates into the fish flesh; while some of the brine drips on the trays where the fish fillets are placed. [25] Found that salt penetrate into the Tilapia muscle by dialysis mechanism whereas water diffuses out of the muscle by the osmotic pressure. The salt content in dry salted Tilapia muscle was higher than that in wet salted Tilapia muscle during the first 10-60 min of salting. This was due to the difference in salt concentration used among the wet and dry salting process. Dry salting used the crystal salt covered directly on the fish surface. This resulted in a greater difference in the concentration of salt between inside and outside of the muscle. Therefore, the salt can penetrate into the flesh effectively. The wet salting using $25 \%$ salt as a salting medium showed the lowered rate of salt uptake when compared to the dry salting process. From the result, the salt content of the products processed with dry salting was greater than of those soaked with salt solution for the same salting time up to $60 \mathrm{~min}$. However, no difference in the salt content in fish muscle of both wet and dry salting was found after $180 \mathrm{~min}$ of salting. This was probably due to the balance of the salt content between the internal part of the muscle and the surrounding brine/crystal salt in both salting processes. Diffusion occurs until the sodium chloride concentration of the system (fish and brine) has equilibrated. A gradual increase in the salt content in wet salted fish was observed with increasing salting time from 0 to $180 \mathrm{~min}$. This result 
indicated the spontaneous uptake of salt by the muscle. Dry salting with a greater difference in the salt concentration between inside and outside of the muscle led to the higher penetration rate of salt into the muscle during the first $30 \mathrm{~min}$. Thereafter, the rate of salt uptake of dry salting process tended to equilibrium resulting in the constant salt content in the muscle. [2] Found that a fast increase in the salted African catfish fillet salt content was observed in the first few hours of the process, followed by a slower increase until equilibrium was attained. Faster salt gain at the first few hours of the salting process can be due to a larger concentration gradient between the brine and the fillets. This gradient is probably reduced with time elapsing as a consequence of a high salt content layer that is formed on the fillet surface and acts as a barrier against further salt uptake [39]. As expected, the rate of salt gain increased with increasing temperature especially when temperature changed from 30 to $32{ }^{\circ} \mathrm{C}$. This complex behavior is certainly related to structural changes in the cell membrane with a reflex on its physical properties and the existence of flow of $\mathrm{NaCl}$ which probably may be due to its smaller molecular size, thus penetrating further into the fillets at high temperature. This effect coupled with the leaching of naturally occurring solutes in the sample may also be responsible for this complex behavior [2].

\section{Quality criteria of salted fish:}

\section{Ph value.}

The average $\mathrm{pH}$ of Mullet fish after 4 month of frozen storage was 6.3 decreased after brining to 6.26 . This may be due to increasing of acids concentration as water migration outside the muscle. Also, smoking process leads to remarkable reduction in the value o moisture as well as the reaction of phenols or polyphenols and carbonyls with protein-SH and amino groups [21]. [13] Concluded that the $\mathrm{pH}$ value of investigated Herring and common Carp fish slightly increased during thawing, while it decreased after salting stage. It was found more decrease in value of $\mathrm{pH}$ after cold smoking. The changes in $\mathrm{pH}$ value of salted anchovy during the ripening process were investigated by [15]. He found that $\mathrm{pH}$ of anchovy muscle appreciably decreased from 6.13-5.72 during the first week of ripening and remained constant until the $8^{\text {th }}$ week. [16] found that the changes in $\mathrm{pH}$ value of fresh and brine salted Rainbow trout were given $\mathrm{pH}$ in muscle in fresh were 6.47 and 6.52 in brine salted $8 \%(\mathrm{w} / \mathrm{w})$ and 6.88 in Brine salted $20 \%$ (w/w) and 6.38 in Dry salted Rainbow trout. [25] Found that the decrease in the $\mathrm{pH}$ of salted Tilapia muscle depended on the salting method applied. The $\mathrm{pH}$ of dry salted fish muscle decreased rapidly in the first 10 min of salting and remained constantly till the end of salting period of $180 \mathrm{~min}$. For wet salting, the $\mathrm{pH}$ of fish muscle decreased up to $30 \mathrm{~min}$ of salting and still unchanged throughout the salting time. The decrease in the $\mathrm{pH}$ of dry salted fish muscle to reach the final value of 5.98 was observed.

\section{Total volatile nitrogen (tvb-n) content.}

TVB-N is one of the most widely used measurements of seafood quality. TVB-N value is an important parameter for determining the freshness of fish products. TVB-N value is affected by species, catching region and season, age and sex of fish. It is a general term which includes the trimethylamine, dimethylamine, ammonia and other volatile basic nitrogenous compounds associated with seafood spoilage [40, 41, 42, 43, 44]. [32] Studied the changes in the TVB-N in gray Mullet and common Carp during salting and curing process. He found that the TVN content increased from $23.49 \mathrm{mg} \%$ in fresh fish to $28.44-81.67 \mathrm{mg} \%$ in the finished product of salt-cured grey Mullet, while it increased from $20.75 \mathrm{mg} \%$ in fresh fish to $121.20 \mathrm{mg} \%$ in the salt-cured common Carp. $\mathrm{He}$ concluded that this wide range of TVN for the finished product might be due to the effect of the different salting treatments on the quality such products. In addition, the TVN of salted fish was affected by salting conditions and the TVN content was higher in the fish salted at room temperature than that salted at lower temperature. [45] Noticed that the TVB-N content of Mullet and Sardine fish showed remarkable upward trend till the end of salting and ripening period. He added that the accepted TVB-N level of Sea Bream and Mullet ranged between $57-60 \mathrm{mg} / 100 \mathrm{~g}$. [46] showed that the TVB-N of freshly caught Mackerel and Sardine reached 12-20 and 16-18 mg/100g, respectively. [47] Observed that TVB$\mathrm{N}$ of raw, salted (brined 10,16\%), cold and hot-smoked silver Carp were 21-36, 26.55-23.23, 30.79-29.62 and 21.52-19.36 mg/100gm (dry basis), respectively. These variations are depending upon the concentration smoking method and storage temperature. [48] suggested that standard of fish freshness as follows: fresh fish TVB-N $<15 \mathrm{mg} / 100 \mathrm{~g}$, sub fresh fish TVB-N 15-25mg/100g, deteriorated fish TVB-N >25mg/100g. [49] Found that the TVB-N content of Mackerel increased during the storage period. They concluded that the rapid increase in TVB-N value may be due to bacterial and enzymatic reaction, particularly the growth of halophilic Bacteria. [13] Showed that the values of TVB-N in raw salted and coldsmoked Herring were 10.63, 18.24, $19.27 \mathrm{mg} / 100 \mathrm{~g}$ (wet basis), respectively. [15] Found that the TVB-N of anchovy decreased from 24.0 to $19.9 \mathrm{mg} \%$ during the first 7 days of ripening thereafter the TVB-N contents of anchovy and brine increased gradually until the end of ripening ( 9 weeks). Moreover, a linear relationship was also observed between the brine TVB-N content and time. On other hand, they concluded that the decrease in anchovy TVB-N content may be due to a part of TVB-N content diffused into the brine with other nitrogen fractions. [50] Found that total volatile nitrogen (TVN) was determined as an index to the degree of putrefaction, decomposition and the degree of proteinases constituent's breakdown, he found also that the amount of (TVN) decreased in eviscerated and non-eviscerated Bori tissues during salting which was due to leaching [51]found that TVB-N content in raw Herring fish was $39.29 \mathrm{mg} / 100 \mathrm{~g}$ and decreased in smoked Herring (brined in $20 \% \mathrm{NaCl}$ for 180 and 90 minutes for whole and gutted Herring fish, respectively) to be $35.1 \mathrm{mg} / 100 \mathrm{~g}$ for whole fish and $30.80 \mathrm{mg} / 100 \mathrm{~g}$ for gutted fish. The same author found that the TVB-N content of salted Herring held in polyethylene bags after 7 days were $41.75 / 100 \mathrm{~g}$ for whole fish and 39.16 $\mathrm{mg} / 100 \mathrm{~g}$ for gutted Herring fish.

\section{Trimethylamine (TMA-N) content.}

TMA is one of the major components of the smell of spoiled marine fish; therefore, TMA levels have been used as an objective index of fish quality. The values of TMA and $\mathrm{NH}_{3}$ showed a redundant pattern of buildup and of reasonable consistent with microbiological data. The standard of fish freshness is very good, good, and intermediate when trimethylamine (TMA-N) $<1-10 \mathrm{mg} / 100 \mathrm{~g}, 10-30 \mathrm{mg} / 100 \mathrm{~g}$, and $30-50$ $\mathrm{mg} / 100 \mathrm{~g}$, respectively $[52,53,46]$. [45] Observed that TMA-N values were $0.07,0.05$, and $0.38 \mathrm{mg} / 100 \mathrm{~g}$ for fresh Mullet, Sea Bream and Sardine samples, respectively. [43] Reported that Trimethylamine (TMA) in seafood is degraded from trimethylamineoxide (TMAO) by microorganism. They found that the TMA content of the salted cod was stable through the storage time (stored at $2,-4,-12,-18$ and $-24^{\circ} \mathrm{C}$ ). The TMA content was $1.70 \mathrm{mg} \mathrm{N} / 100 \mathrm{~g}$ in salted cod. The TMA content of all samples decreased after storage for 3 weeks. After that, the TMA content of the samples stored at $2^{\circ} \mathrm{C}$ and $-4^{\circ} \mathrm{C}$ increased again. Meanwhile, the TMA content of other samples continued decreasing at the end of the storage period. Castell (1970) found that the determination of Trimethylamine nitrogen is considered as an index of fish quality and freshness. He also added that the increase of TMA indicates the breakdown of proteins, lipids and TMA-oxide causing the formation of TMA. It is a pungent volatile amine often associated with the typical fishy odour of spoiling seafood. The level of TMA found in fresh fish rejected by sensory panels varies between fish species, but is typically around $10-15 \mathrm{mgN} / 100$ $\mathrm{g}$ in aerobically stored fish [41]. The variation in the acceptability level can be attributed to the fact that TMA values vary with species, season, storage conditions, bacteria and intrinsic enzyme activity [54]. [13] Found that TMA-N value was $0.39 \mathrm{mg} \backslash 100 \mathrm{~g}$ in Herring fish, $1.73 \mathrm{mg} \backslash 100 \mathrm{~g}$ in salted Herring.

\section{Thiobarbituric acid (tba) value.}


The oxidative rancidity in fat containing foods lead to formation of malonaldehyde (MA) or derivatives of this compounds therefore the red reaction product formed by the reaction of MA and 2-thiobarbaturic acid (TBA) is an effective mean of measuring the extent of autooxadition. The good quality fish had a TBA less than $3 \mathrm{mg}$ MDAlkg while products of poor quality had values from 4-27 mg MA $\mathrm{kg}$ samples[55]. [32] Found that the TBA values (mg MAlkg sample) increased sharply from $5.93 \mathrm{mg}$ MAlkg in fresh grey Mullet to 14.43-78.0 mg MAlkg after 4 weeks from the beginning of salting. [56] noticed that the determination of the 2thiobarbituric acid value is one of several analytical methods for the evaluation of the degree of oxidation ofvegetable oils, fish oils and animal fats, particularly those containing linolenic acid and more unsaturated fatty acids. 2-thiobarbituric acid forms red-coloured products with malonaldehyde (1), some polyunsaturated aldehydes (2), dioxolanes and furan derivatives. The intensity of coloration is correlated with the rancidity degree of fats and oils. [57] said that recently, there is increasing international concern aboutthe prescience and the adverse effects of some toxic compounds such asmalonaldhyde, it is formed in fresh and ready to eat food including cheeseas a consequence of oxidation of their contents of polyunsaturated fatty acids during storage, processing and cooking. Alternatively the $\mathrm{Na}+$ mayreplace the iron from a cellular complex via an ion exchange reaction. The displaced iron may then participate in the initiation of lipid peroxidation [58].TBA has been used to measure the concentration of relatively polar secondary reaction products, especially aldehydes [59].The decrease in TBA has been attributed to the interaction of decomposition products of protein with malonaldehyde to give tertiary products [49]. [13] Observed that TBA values were 0.21 and 0.55 mgMAlkg (wet wt.) in raw and saltedHerring fish samples. [15] found that the TBA content in raw anchovy fish was $10.7573 \mathrm{mg} \mathrm{MA} / \mathrm{kg}$ increased during first 6 weeks of salting $(12.73 \mathrm{mg} \mathrm{MA} / \mathrm{kg})$ and thereafter decreased gradually (11.92 and $11.45 \mathrm{mg} \mathrm{MA} / \mathrm{kg}$ after 7 and 9 weeks of salting, respectively). [51] Found that TBAvalue was 0.096 as O.D. at $538 \mathrm{~nm}$ in raw Herring and increased in saltedfish samples. The increase in TBARS indicated the formation of secondary lipid oxidation products [60]. [61] Reported that increasing thesalt content in fish muscle accelerates the rate of oxidative rancidity in salted Horse Mackerel during frozen storage. [25] Found that the rate of lipid oxidation of Tilapia muscle, as measured by increased TBARS, wasgenerally higher in dry salting when compared to wet salting, especially at the end of salting period. This was because of the dry salting facilitatingthe salt uptake into the fish muscle effectively.

\section{Microbiological hazards.}

The microbial status of seafood after catch is closely related to environmental conditions and microbiological quality of the water. These factors include water temperature, salt content, distance between localization of catch and polluted areas (containing human and animal feces), natural occurrence of bacteria in the water, ingestion of food by fish, methods of catch and chilling, and post-harvest handling or processing conditions [62]. [63] Found a significant change in some chemical constituents of salted Tilapia fish (Oreochreomis niloticus). All number of microorganisms increased rapidly during the first fermentation days and then began to decrease. [5] Found that in freshest raw cod, 10 of the approximately 30 tested strains grew in salt concentrations up to $8 \%$, and survived in $20-25 \% \mathrm{NaCl}$ for at least 3 days, indicating that they could survive both at high and low salt concentrations. [64, 65] [66] determined the aerobic bacterial counts of fresh Mediterranean Sardines (clupea pilchardus) and ther values were $3.5 \times 10^{4} \mathrm{CFU} / \mathrm{g}$ of flesh , $9 \times 10^{3} \mathrm{CFU} / \mathrm{g}$ of skin and $13 \times 10^{3} \mathrm{CFU} / \mathrm{g}$ of gills for fresh Sardine. [67] Found that Microbial counts on the red Mullet and gold band goatfish (Upeneus moluccensis) kept in ice are increases in total viable counts (TVC) over the period of storage. TVC for fish exceeded $7 \mathrm{log}$ CFU/g considered as the maximum level for acceptability for freshwater and marine fish after 8 days for goldband goatfish, and 11 days for red Mullet. Bacteria grew more quickly in goldband goatfish than red Mullet during the storage periods. This conclusion implies that sensory analysis correlated well with the microbiological analysis of the fish. [68] Reported that fish in general usually spoil more rapidly than other muscle foods, particularly when mishandled and such spoilage is primarily bacterial in nature, about $30 \%$ of landed fish are lost through microbial activity alone. Fish is one of the most perishable foods and its preservation is usually accomplished by combination of different techniques. Contamination with spoilage microorganisms is almost unavoidable because fish is a very good culture media. Therefore, good fish preservation techniques must prevent microbial spoilage of fish without affecting its quality and nutritional value. Fish is low acid food and is therefore very susceptible to the growth of food poisoning bacteria. Spoilage of fish can be due to rapid autolysis by the fish enzymes, and because of less acid reaction of fish flesh that favors microbial growth [69]. [70] Noticed that the most fish flesh, however, is considered more perishable than meat because of more rapid autolysis by the fish enzymes and because of less acid reaction of fish flesh that favors microbial growth.

\section{Sensory evaluation:}

Sensory evaluation is considerable very important parameter to control of fish quality as raw and processed product. Also, it plays a specific role as a repaid method for assessing the freshness, bedside physico-chemical and microbiological determinations. Organoleptic measurements are including the following parameters: appearance, flavor, texture, etc. which carried out by judgments [71]. It could be considered that flavor alone is main factor for purchasing more than texture. However, the texture is more important by some evidence for it on a relative bases [72]. [47] reported that the silver Carp fish treated with brining in $10 \%$ $\mathrm{NaCl}$ concentration followed by cold-smoking and storage at refrigeration had good acceptability scores of organoleptic properties. [12] found that smoking process give a higher average scores in texture, juiciness, odor as well as overall acceptability .smoking of Mullet fish imparts a mild flavor, color and all other sensory attributes were judged by panelists to be extremely very much. He was added that during the first 10 days of storage most sensory attributes did not show any significant changes, andafter 120 days storage, smoked Mullet fish was judged organoleptically to be unacceptable as a result of odor and taste deterioration. [6] Found thatwhen experimentally dried Sardine fish and commercial dried ones were studied for organoleptic evaluation, $21 \%$ brine salted fish were preferred for appearance, texture and overall acceptability. Dry salted fish become brittle and easy to break. A white crusty layer was visible on the outside of the fish due to the higher salt content on the surface. Commercial sun dried Sardines had the worst overall acceptability, and were not easy to handle being very brittle. [67] Found that the initial quality characteristicsof the red Mullet and goldband goatfish stored in ice were very bright appearance, hard texture, bright and convex eyes and fresh odors. Demerit points increased in the two species with storage time. Although the initial sensory scores for the two species were the same on day 0 , the scores for goldband goatfish were higher than for red Mullet at days 8 and 11. The acceptable shelf life was found to be 8 days for goldband goatfish (demerit score: 13.17) and11 days for red Mullet (demerit scores: 13.83). The results of the sensory analysis indicated that the storage lives of these fish belonging to the same family were different.

\section{References}

1. Turan H, Sönmez G, Çelik MY and Yalçin M (2007) Effects of different salting process on the storage quality of Mediterranean Muscle (MytilusGalloprovincialis). J. of Muscle Foods 18:380390.

2. Sobukola OP and Olatunde SO (2011) Effect of salting techniques on salt uptake and drying kinetics of African catfish (Clariasgariepinus).J. of Food and Bioproducts Processing, 89: 170-177. 
3. Wang D, Tang J and Correia LR (2000) Salt diffusivities and salt diffusion in farmed Atlantic salmon muscle as influenced by rigor mortis. J. of Food Engineering, 43: 115-123.

4. Jittinandana S, Kenney PB, Slider SD and Kiser RA (2002) Effect of brine concentration and brining time on quality of smoked rainbow trout fillet. J. of Food Science, 67 (6): 20952099.

5. Barat JM, Gallart-Jornet L, Andre's A, Akse L, Carleho G M and Skjerdal O T (2006) Influence of cod freshness on the salting, drying and desalting stages. J. of Food Engineering, 73: 9-19.

6. Bellagha S, Sahli A, Farhat A, Kechanou N and Glenza A (2007) Studies on salting and drying of sardine (Sardinellaaurita): experimental kinetics and modeling. J. of Food Engineering, 78: 947-952.

7. Gallart-Jornet L, Barat JM, Rustad T, Erikson U, Escriche I et al (2007) A comparative study of brine salting of Atlantic cod (Gadusmorhua) and Atlantic salmon (Salmosalar). J. of Food Engineering. 79(1): 261-270.

8. Bremner H A (Ed.) (2002). Safety and quality issues in fish processing. Elsevier.

9. Aman M.E and Shehata AA (1978) Effect of prolonged frozen storage and after heat treatment on lipid changes in the muscle of sheat. J. of fish , Alex. Agric. Res., 26(1):145

10. Wheaton FW and Lawson TB (1985) Processing Aquatic Food Products. John wiley and sons. New York, U.S.A.

11. Rashad FM (1986) Bacteriological and chemical studies on salted mullet fish "Feseekh" a traditional fermented fish product in Egypt. Ph.D. Thesis, Fac. Agric , Cairo Univ, Egypt

12. Yasin, N.M. (1997). Studies on the expiration period and quality attribute of some fish products. M.Sc. Thesis. Fac. of Agric., Ain Shams univ.

13. Hegazy NM (1998) Biogenic amines changes during smoking and cooking of some fish species. Ph.D. Thesis Fac. of Agric. Cairo univ.

14. Awad AM (1999) Physical and chemical studies on some factors affecting the quality of salted anchovy. Ph.D. Thesis, Fac., of Agric., Fayoum, Cairo Univ.

15. Hernandez-herrero MM, Roig-sagues AX, Lopez-sabater EI ,Rodriguez-Jerez JJ, and Mora-ventura, MT (1999) Total volatile basic nitrogen and other physcochemical and microbiological characteristics as related to ripening of salted anchovies. J. of Food Science, 64(2).

16. Unlusayin M, Erdilal R, Gumuş B and Gulyavuz H, (2010). The effects of different salting methods on extract loss from Rainbow Trout. J. of Pak Vet. 30(3): 131-134.

17. Thorarinsdottir KA, Arason S, Bogason S G and Kristbergsson $\mathrm{K}$ (2002). Changes in myofibrillar proteins during processing of salted cod (Gadusmorhua) as determined by electrophoresis and differential scanning calorimetry. J. of Food Chemistry, 77 (3: 377-385.

18. Offer $G$ and Knight $P$ (1988). The structural basis of water holding in meat. In: " Developments in Meat Science". R. Lawrie (Ed.), London: Elsevier, pp: 63-171.

19. Kelleher SD and Hultin HO (1991) Lithium chloride as a preferred extractant of fish muscle proteins. J. of Food Science, 56: 315-317.

20. Stefansson G and Hultin HO (1994) The solubility of cod muscle proteins in water. J. of Agric, and Food Chem., 42: 2656-2664.

21. Kinsella JE (1982). Relationships between structure and functional properties of food proteins. In: "Food Proteins". P. F. Fox, and J. J. Condon, (Eds.), London: Applied Science Publishers.
Morrissey PA, Mulvihill DM and O’Neill, E. M. (1987). Functional properties of muscle proteins. In: "Developments in Food Proteins". B. J. F. Hudson, (Ed.). New York: Elsevier Applied Science, pp: 195.

23. Barat JM, Rodríguez-Barona S, Andrés A and Fito P (2002) Influence of increasing brine concentration in the cod salting process. J. of Food Science, 65 (7):1922-1925.

24. Martinez-Alvarez O and Gomez-Guillen, M.C. (2006). Effect of brine salting at different $\mathrm{pHS}$ on the functional properties of cod muscle proteins after subsequent dry salting. J. of Food Chemistry, 94: 123-129.

25. Chaijan M (2011). Physicochemical changes of Tilapia (Oreochromisniloticus) muscle during salting. J. of Food Chemistry, 129: 1201-1210

26. Thorarinsdottir KA, Arason S, Digurgisladottir S, Valsdottir T and Tornberg E (2011) Effect of different pre-salting methods on protein aggregation during heavy salting of cod fillets. J. of Food Chemistry, 124:7-17.

27. Del Valle FR, Padilla M, Ruz A and Rodriguez R (1973) Pilot plant production and large scale acceptance trials with quicksalted fish cakes. J. of Food Science. 38:246-250.

28. FAO (1981) Food and Agriculture Organization. The preservation of losses in cured fish. Technical Paper No. 219.

29. Jacquot R (1961) In: Fish as Food. G. Borgstorm (Ed.), Academic press, New York, USA, pp. 145-209.

30. Love R M (1970) The chemical biology of fishes. Academic Press, New York.

31. Martinez-Alvarez O and Gildberg A (1988) Autolytic degradation of belly tissue in anchovy (Engraulise crasicholus), Int. J. of Food Sci. Technology, 23: 185.

32. El-Sebaiy L A and Metwalli SM (1989) Changes in some chemical characteristics and lipid composition of salted fermented Bouri fish muscle (Mugilcephalus). J.of Food Chemistry. 31(1): 41-50

33. EL-Sharnouby SA (1989) Chemical and technological studies of fish "role of enzymes in determining the quality of salted and cured fish".Ph.D. Thesis, Fac.of Agric. Alexandria. Univ.

34. Al-Habib FM and Al-Aswad MB (1985). Some chemical and physical changes in some frozen Iraqi fish. Zanco, 3(4): 35-50.

35. Birkeland S, Sivertsvik M, Nielsen H H and Skara T (2005). Effects of brining conditions on weight gain in herring (Clupeaherengus) fillets. J. of Food Engineering, 70: 418-424.

36. Heredia A, Andre's A, Betoret N and Fito P (2007) Application of the SAFES (systematic approach of food engineering systems) methodology to salting, drying and desalting of cod. J. of Food Engineering, 83: 267-276

37. Berhimpon S, Souness RH, Buckle KA and Edwards RA (1990) Salting and drying of yellow tail (Tachurusmcculochi Nichols). International J. of Food Science and Technology, 25: 409-419.

38. Fuentes A, Barat JM, Fernandez-Segovia I and Serra JA (2008) Study of Sea Bass (Dicentrarchuslabrax L.) salting process: Kinetic and thermodynamic control. J. of Food Control, 19:757763.

39. Fuentes A, Fernandez-Segovia I, Serra J A and Barat JM (2007) Influence of the presence of skin on the salting kinetics of European Sea Bass. International J. of Food Science and Technology, 13(3): 199-205.

40. Mujaffar S and Sankat CK (1998) The osmotic dehydration of shark fillets, In International Drying Symposium 11 (Ziti Publishing, Halkidiki, Thessaloniki), p: 911-921. (Ziti Publishing, Halkidiki, Thessaloniki).

41. Gill T A (1990) Objective analysis of seafood quality. J. of Food Review International, 6:681-714.

42. Huss H (1995) Quality and Quality Changes in Fresh Fish. FAO Fish. Tech. Pap. 348. FAD Rome. Italy. 
43. Gokoglu N, Ozkan O and Erakan N (1998) Physical, chemical and sensory analyses of freshly harvested sardines (Sardinapilchardus) stored at $4 \mathrm{oC}$. J. of Aquaculture and Food Product Technology 7: 5-15.

44. Van M N (2007) The effects of storing and drying on the quality of cured, salted cod. Final project of fisheries training program, University of United Nations, P.O. Box 1390, Skulagata 4, 120 Reykjavik, Iceland

45. Kung H F , Chien L-T, Liao H-G, Lin C-S, Liaw E-T, et al (2008) .Chemical characterisation and histamine-forming bacteria in salted mullet roe products. J. of Food Chemistry, 110: 480-485

46. Shalaby AR (1990) Correlation between freshness indices and degree of fish decomposition. Ph.D., Thesis, Fac. of Agric., Ain Shams Univ.

47. Bennour M, EL-Marrakchi A, Bouchriti N, Hamama A and ELQuadaa M (1991) Chemical and microbiological assessment of mackerel (Scomberscombrus) stored in ice. J. of Food Port. 54:789.

48. Abd El-Mageed SA (1994) Chemical and technological studies on fish smoking. M.Sc. thesis, Fac. of Agric., EL-Azhar Univ., Cairo, Egypt.

49. Sheh L (1996) Amperometric determination of fish freshness by a hypoxanthine biosensor. Journal of Science. Food Agric.,70: 298-302.

50. Reddy KP, and Settee TMR (1996) An intermediate moisture product from mackerel (Rastrelligerkanagurta) using salt curing, fermentation and drying. J. of Aquatic Food Production and Technology, 5: 65-82.

51. Shaheen AB (1958) Chemical composition of salted fish (feseekh) at various storages of fermentation. M.sc. Thesis, Cairo University.

52. Ibrahim SM (1999) Application of HACCP system in controlling hazards of some fish products. Ph.D., Thesis, Fac. Of Agric., Ain Shams univ., Cairo, Egypt.

53. Chang GW, Shultz DE and Bjeldanes LF (1976) Rapid thin layer chromatographic method for the determination of histamine in fish products. International J. of AOAC. 59 (6): 1224-1225.

54. Brown WD, Arnold SH and Price RJ (1980). Histamine formation by bacteria isolated from skipjack tuna, (Katsuwonaspelamis) Bull. J. of Soc. Sci. Fish. 46: 991-995.

55. Debevere J and Boskou G (1996). Effect of modified atmosphere packaging on the TVB/ TMA-producing microflora of cod fillet. International J. of Food Microbiology 31: 221229.

56. Sinnhuber RO and Yu TC (1958) 2-Thiobarbituric acid method for measurement of rancidity in fishery products. II. Quantitative determination of malonaldehyde.J. of Food Technol. 12:9-12.

57. Pokorny J and Dieffenbacher A (1989). Determination Of 2Thiobarbituric Acid Value: Direct Method, Results of a collaborative study and the standardized method. J. of Pure and Appl. Chem., 61(6): 1165-1 170.

58. Gray JI and Morton DI (1981). Some toxic compounds produced in food by cooking and processing. A Review J. of Human Nitration, 35:5-23.
Hultin HO (1992). Lipid oxidation in fish muscle. In: "Advance in Seafood Biochemistry".G. J. Flick, and R. E. Martin (Eds.). New York, USA, 1992, PP;99-122.

60. Nawar WW (1996) Lipids. In: " Food chemistry". O. R. Fennema, (Ed.), New York, USA: Marcel Dekker, Inc pp: 225314.

61. Kolakowska A (2002) Lipid oxidation in food systems. In: "Chemical and Functional Properties of Food Lipids". Z. E. Sikorski and A. Kolakowska, (Eds.), FL, USA: CRC Press, PP: 133-160.

62. Augbourg S and Ugliano M (2002) Effect of brine pre-treatment on lipid stability of frozen Horse Mackerel (Trachurustrachurus). European Food Research and Technology, 215:91-95.

63. Feldhusen F (2000) The role of seafood in bacterial foodborne diseases.J. of Microbe Infection, 2:1651-1660.

64. Abu Gideiri BY, Ali ME and Abu Zied IM (2004) Review of research on the Nile bulti, (Oreocheomis niloticus) (Trewavas) in Sudan. pp: 43-44.

65. Gennari M, Ferrini Fand Tomaselli S (1988). A Study of Pseudomonas and allied bacteria involved in the spiolage of Sardines stored in Ice. J. of ArchivioVeterinarioItaliano, 39(516): 209-227.

66. Gennari M, Alacqua G, Ferri F and Serio M (1989) Characterization by Conventional Methods and genatic transformation of Nesseriaceae (Genera Psychrobacter and Acinetobacter) isolated from fresh and spioled Sardines. J. of Food Microbiology, 6(4): 197-210.

67. Beltran A, Pelaez C and Moral A (1989) Keeping quality of vacuum-packed smoked sardine fillets: microbiological aspects. J. of Z. LebensmUntersForsch. 188:232-236.

68. Ozyurt G, Kuley E, Ozkutuk S and Ozogul F (2009) Sensory, microbiological and chemical assessment of the freshness of red mullet (Mullusbarbatus) and goldband goatfish (Upeneusmoluccensis) during storage in ice. J. of Food Chemistry, 114: 505-510.

69. Ghaly AE ,Dave D, Budge S and Brooks MS (2010) Fish spoilage mechanism and preservation techniques review. American J. of Applied Sciences, 7(7): 859-877

70. Yohnna J, Fulani AU and Aka ama W (2011). Prospects for adaptable technological innovation in fresh fish processing and storage in rural area of Domal L. G. A. of Nasarwa a State. J. of Agricultural Science, 3(3): 282-286.

71. Ghada HA, Abu Gideiri BY, Ali ME and Abu Zied IM (2012) Quality Preservation in Salted Fermented debs sp. (Lebeo sp.) during storage period. J. of New York Science, 5(2).

72. Connel JJ and Shewan JM (1980) Sensory and nonsensory assessment of fish. In: 'Advances in Fish Science and Technology". J.J. Connell (Ed.), Fishing News Books Ltd., Farnham, Surrey, U.K., 1980, PP: 56-65.

73. Sawyer FM , Cardello AV and Prell PA (1988) Consumer evaluation of sensory properties of fish. J. of FoodScience, 53: $12-24$.

74. Castell CH (1970) Current status of the trimethylamine test as a measure of spoilage of fish. Fisheries Research Board of Canada, 22:16-20. 